\title{
Formation of Vocational Competence of Future Specialists in Physical Education and Sports
}

Julia Kovalenko', Kateryna Gnatenko², Olena Fedorenko ${ }^{3}$, Lubov Karpets ${ }^{4}$, Roman Kovalenko

Kharkiv State Academy of Physical Culture, 99 Klochkivska St, UA-61058 Kharkiv, Ukraine, julawa09@gmail.com Kharkiv State Academy of Physical Culture, 99 Klochkivska St, UA- 61058Kharkiv, Ukraine, malekk26@gmail.com Kharkiv National University of Internal Affairs, 27 Landau Ave., UA-61080 Kharkiv, Ukraine, fei090771@gmail.com Kharkiv State Academy of Physical Culture, 99 Klochkivska St, UA-61058 Kharkiv, Ukraine, lubo.karpets@gmail.com V. N. Karazin Kharkiv National University, 4 Svobody Sq., UA-61022 Kharkiv, Ukraine, roman.kovalenko@karazin.ua

\begin{abstract}
The objective of the study is to determine the components of the formation of vocational competence of future specialists in physical education and sports. Analysis of components of students in the specialties "Management in sports activities" and "Secondary education (Physical education)" was made. Comparative characteristic of partial readiness for the professional and pedagogical self-development of the first and fourth-year students was conducted.
\end{abstract}

Keywords: competence, professional competence, sports specialists, physical culture, management, professional culture.

\section{Introduction}

In the context of globalization, technological explosion, and rapid economic progress, basic and social competences are of great importance. There is reason to believe that only a competent approach to the professional training of future professionals enables one to successfully combine both their own interests and those of society. Our present day, active European integration of all spheres of public life require changes in the professional activity of every member of society. 
The transition to a market economy, integration into the international educational space, democratization, and humanization of public life in the country have become more relevant. The state is facing socio-economic transformations that have given rise to new tasks related to the improvement of higher education, physical education, and sports system as well. These tasks will be solved under the conditions of forming value orientations of the population aimed at promoting health, organizing healthy lifestyles, increasing the level of physical education of young people, which today are of deep concern and become a significant challenge for society at the present stage of its development (Dubrevskiy, 2014). However, the dynamic development of society also places new demands on the higher vocational education system in Ukraine. First of all, changes in the economy require the use of new methods and approaches in the educational field of specialist training. The current stage of development of the sphere of physical culture and sports stipulates new requirements for personnel support of this sphere of humanitarian policy.

Development of sports and sports movement in market conditions is impossible without professionally trained, competent specialists, who will carry out their activity on a professional basis, ensure activation of innovative activity, the formation of effective investment policy and social infrastructure in the country, development of sports services, etc.

The future specialist should not be an object, but a conscious subject of training. Professional knowledge should be of particular importance to a student who not only receives them, but is also aware of the importance of this knowledge for himself and his activities and is able to apply this knowledge effectively. With such training, the process of knowledge transfer from the teacher to the student takes place, where they need to display their knowledge and skills in non-standard situations that mimic professional activity. In this case, the result of education is not the quality of the acquired knowledge, but the quality of mastering this knowledge when solving professional problems.

Theoretical analysis of the pedagogical experience of professional training of future specialists of physical culture and sports in foreign countries will allow it to be considered in the process of modernization of the system of vocational education for training specialists of the appropriate field in modern Ukraine. It is as a result of a comprehensive analysis of the system of training of specialists in physical culture and sports within the framework of higher professional education of foreign countries is a real opportunity to use this experience to improve the process of training of these specialists and the level of their professional competence in Ukrainian universities. 


\section{Literature review}

Against this background, we analyzed the level of professional competence of future sports specialists and future physical education teachers. The study was conducted considering the analysis of the work of different specialists in this area.

Much attention is paid to the professional competence of the teacher in the works of Akapiev and Savotchenko (2016), Kartseva (2013), where the components of the teacher's key competencies were identified.

Content and structure of competencies of management activity are considered on the basis of analysis of judgments and views of such scientists as Harmash (2017), (management competencies), Svertnev (2018) (the content of the cognitive-operational sphere of the sports manager) and others, considering the basic principles of management. Both theoretical and practical foundations of the professional training of future specialists in physical culture and sports and criteria, levels and components of professional competence of a physical education teacher were investigated in the works by Dubrevskiy (2014), Kryshtanovych (2018).

In particular, Michuda (2007) dedicated his work to the coverage of the experience of training specialists in the field of sports management at higher education institutions in Western European countries. Osadcha (2006) and Rychkova (2016), reviewed the process of professional training of physical education teachers at US universities.

The works of foreign researchers on the development of physical culture are analyzed by Castelli and Beighle (2007), Chen and Ennis (2004), improving the work and curricula of physical education teachers such as Zhu and Ennis (2011), integrated competence approach of physical education teachers Ennis (2013), Kovač et al. (2008), Awad and Eid (2013). The problem of professional competence of physical education specialists was handled by Srisawat et al. (2015), Aghaen and Hoseini (2018), Batista (2011) et al.

The development of qualification characteristics and professiograms to the content of the activity of the teacher by such authors as Bermudes and Loza (2017), was analyzed. We also relied on research into the structure of pedagogical activity and its components by Zhyhir (2015) and researches of different types of competencies as a component of professional competence, conducted by Shumigora (2019) and others. They connect the concepts analyzed with the phenomenon of culture, namely professional culture. In this regard, the assimilation of culture is personal growth and becoming him as a creative and professional personality. Scientists believe that vocational competence is directly related to the professional culture and they prove it in their researches.

Nevertheless, Kuzmina (2014) considers professional competence as the personal capabilities of a specialist, which allow him to achieve professional goals independently and effectively. On the other hand, Svertnev (2018), Fedorenko (2018) view these concepts in terms of a systematic approach. 
The analysis of the data of domestic and foreign scientists showed that a lot of attention was paid to the vocational competence of physical education teachers, and the professional competence of sports specialists is little studied and needs additional research.

The study purpose is to determine the components of the formation of professional competence of future sports professionals.

\section{Theoretical Analysis}

The introduction of a competence approach to the system of professional training of specialists necessitates the study of the content and structure of different competences. Most students dream of senior management positions of varying managerial level. Thus, they need to acquire new knowledge of economics and management, learn how to use them in practice, and constantly improve them. This issue does not lose relevance over time, as the tasks of professional training of specialists in different specialties and the conditions of their realization change dynamically and naturally (Kovalenko, 2019).

Methods of formation of professional competence of future specialists of sports activity should be based on: observance of requirements for training of future specialists; determination of the content of their professional training in universities; scientific approaches to the organization of educational activities at the university; selection of practice-oriented tasks, situations that mimic economic, managerial problems of the content of the professional activity of future specialists in the field of physical culture and sports; use of interactive teaching methods; the interconnection of individual and group, classroom and independent work of students based on the principle of cross-curricular coordination; use of multimedia technologies and more.

The changes taking place in physical education require the use of new methods and approaches in the educational sphere of training of future teachers of physical education, namely their professional culture. These requirements apply to professionals in any field of physical education and sports.

Professional culture is an indicator of the social maturity of the personality of a specialist in physical education, unites a complex of professional knowledge, skills, personal qualities.

Professional culture is one of the most important socio-cultural factors of becoming a future specialist. As an element of the general culture, the professional culture of the future specialist is based on generally accepted spiritual and moral values, norms and rules, as well as the ways of interaction of the specialist as a unit of the social system to which he belongs. However, the general culture is distinguished by the norms and standards of life that are common to people, regardless of their direction of activity (Hnatenko, 2019).

The current stage of development of Ukrainian society establishes new requirements for the personality of the teacher as a whole and, in particular, the trainer-teacher, 
which is connected with the main global social, economic, psychological-pedagogical, socio-cultural changes that are happening in our country and the world, as well as the trend integration of Ukraine into the European economic and socio-cultural space (Kovalenko, 2015).

The educational standard of professional training of sports managers is intended to solve the problems of the formation of vocational and communicative competence, as well as critical thinking. The innovative principle of its construction is reflected, first of all, for the purposes of training, providing mastery of competences based on basic knowledge and skills acquired in the process of training future specialists.

Competence - good awareness of something; the terms of reference of any organization, institution, or person; the set of rights and responsibilities entrusted to a business in a particular industry, institutions, organizations, or officials. Competency-awareness, competence, or authority in any industry.

It has been found that in the field of physical culture and education, the concept of "competence" is interpreted as a universal prerequisite for the professional development of a person in a real socio-economic situation in accordance with the conditions in society; a field of activity in which professional competence is exercised.

In pedagogical science, the term "competence" defines new realities and tasks in connection with preparing young people for active participation in public life. Competence is the quality of a person, which implies the possession of certain competencies. In turn, professional competence is viewed as an individual characteristic of the degree of conformity to the requirements of the profession; individual-psychological formation which includes experience, knowledge, ability, professionally important qualities, psychological readiness (Dubrevskiy, 2014).

In recent years' scientific research, the concept of "competence" is seen as the highest level of professional activity studied in acmeology by Derkach and Zazykin (2003). That is why scientists of the acmeological direction concluded, that for the effective implementation of professional management activity the head of a sports institution must possess not only professional activity, but also professionalism of the individual (Derkach\& Zazykin, 2003).

\section{Methodology}

The methodological basis of modern research on vocational education is the competency approach, which is justified in the "National Educational Glossary: Higher Education" as "an approach to defining learning outcomes based on their description in terms of competencies". It is also noted: "A competent approach is a key methodological tool for achieving the goals of the Bologna Process". The competency approach reveals the goals, content, and methodology of vocational education. The vocational competence of future 
specialists in the sports industry is considered as a holistic characteristic of the individual, the combination of knowledge, skills, and habits that produce professional intelligence, professional positions, and individual-psychological characteristics of these specialists.

The professional competence of a specialist in the field of physical education and sports is considered as an integrated professional and personal characteristic in the programs of educational institutions, which should ensure the effective level of their professional activity and reflect the level of professional competence that is determined by the set of motivational and value attitudes, which are due to the necessary skills and values, level of professional skill and experience in the chosen field of activity.

The competence of a specialist is manifested in the activity and characterizes the ability to solve problems, his ability to self-esteem, self-analysis, self-awareness. The formation of competence goes through several levels consistently: from the level of to "know" to the level of to "make". Competence is considered to be formed when it reaches the level of "to show how".

The development of modern vocational education is accompanied by the emergence of a large number of different approaches to training specialists. Among them are wellknown and well-established (knowledge-centrist, systemic, activity-based, complex, personality-oriented, personality-activity) and relatively new ones, which have recently entered into theory and practice (situational, contextual, poly-paradigmatic, informational, etc.). The latter includes the competence approach.

The purpose of the competence approach is to ensure the quality of education. The competence approach is a priority orientation on the goals - the vectors of education: learning, self-determination, self-actualization, socialization, and development of personality.

As the concept was mastered, its volume and content were expanded, and already from the end of the last century, they began to speak of a competency-based approach to education. Scientists considering the competency-based approach to designing a multi-level higher education, provide the rationale for the transition of the domestic educational system to a new qualitative state based on the implementation of the competency-based approach as a methodological principle for designing multi-level education (Paula\& Fazendeiro, 2011).

The analysis of various publications devoted to the emergence and development of the idea of a competency-based approach showed that initially, it was a question of professional competences of the individual as the goal of education. At the same time, competence was understood as in-depth knowledge of the subject or acquired skill. As the concept was mastered, its content was expanded.

The essential characteristics of competence form the basis of a new approach to vocational education. Shumigora (2019) claims that the purpose of vocational education is not only to teach a person to do something, to acquire professional qualifications, but 
also to give him the opportunity to cope with various business and life situations and work in a group (Shumigora, 2019).

Thus, the competency-based approach in education is associated not only with the acquisition of knowledge, training in performing specific functions, but also with the formation of the abilities necessary for successful professional activities.

The implementation of the competency-based approach in vocational education is associated with the concepts of "competence" and "competency".

An important condition for the development of key competencies of a specialist is key qualifications (general professional knowledge, abilities, skills, as well as personal abilities and qualities necessary to perform work in the context of his profession). A fullfledged process of professional development of a person is possible only with a developed system of its ideas about it as a specialist with a high level of professional competence. When training a future specialist, it is important to pay attention to the development of a block of professionally important qualities, to develop an attitude toward personal and professional self-improvement, which is achieved by creating certain conditions for students to learn their motives, opportunities for realizing personal qualities.

\section{Study organization}

The results of the scientific research made it possible to identify the following components of the study of professional competence of future specialists in the sports industry: motivational and value component, which in particular is a component of professional culture, moral-willed, cognitive, gnostic, and professional-personal component. It is these components that have been selected by the indicators of measurement, the number of measurements of which are the indicators.

We refer to the motivational value component as a set of conscious motives, on which the choice of actions to improve professional skills and, above all, awareness of the importance of professional self-actualization, motivation for success and result through solving professional tasks, interest in the management of professions and interest, depends on.

We define the moral-volitional component as a complex of abilities and skills of application of volitional qualities of the personality, communicative skills and ability to solve difficult communicative situations, adding conflict, through the management of knowledge in professional activity.

The cognitive component is defined as the set of knowledge and methods of their use in professional activity, namely, knowledge about the professional and psychological activity of future teachers of physical culture and future managers of sports activities.

The professional-personal component is understood as a complex of professional and personal qualities, abilities and properties that promote effective professional activity, which are conditioned by the development of leadership and creative abilities to selfdevelopment and effective development of professional qualities. 
Gnostic component encompasses the ability to set and successfully solve cognitive tasks through the flexibility and efficiency of thinking, the ability to analyze pedagogical activity and professional activity in general, the ability to synthesize and generalize, the ability to prove and justify judgments, the ability to systematize and classify and classify to see contradictions and to identify problems, to be able to transfer acquired knowledge and skills to new situations in professional activity.

The organizational component is a set of skills such as the ability to plan time and activity, the ability to design, and build a system of personal professional activity for future professionals in the field of sports.

Particular attention was paid to such a component as the ability to self-government, namely, self-esteem in professional activity, the ability to self-reflection, and reflection, the ability to self-control and mobilize in professional activity.

The communicative component implies the ability to accumulate and use the professional experience of more experienced employees in their industry, the ability to cooperate and assist each other, the ability to defend their point of view, to persuade and motivate others, the ability to anticipate conflicts and problematic situations.

\section{Study participants}

Groups of first- and fourth-year students of the Kharkiv State Academy of Physical Culture, specializing in Management in Sports Activity and Secondary Education (Physical Education), were selected for analysis, due to their experience of teaching, self-studying and the amount of knowledge and skills.

The survey is aimed at the diagnosis of the level of partial readiness for professional and pedagogical self-development.

The survey was conducted among 40 first- and fourth-year students of the Kharkiv State Academy of Physical Culture. The questionnaire became the diagnostic tool of the questionnaire "Diagnostics of the level of partial readiness for professional and pedagogical self-development” (Fetiskin et al., 2002).

\section{Research Results}

It is this research questionnaire that helps to start the study of students' professional competence. According to their cumulative results, in the course of the research we analyze the formation of professional competence and the general level of readiness of students of Kharkiv State Academy of Physical Culture to participate in professional activity. See Table 1. 
Table 1

Partial Readiness for Professional and Pedagogical Self-Development

\begin{tabular}{|c|c|c|}
\hline Components & $\begin{array}{l}\text { First-year students in the } \\
\text { specialty "Management } \\
\text { in sports activities" }\end{array}$ & $\begin{array}{l}\text { First-year students in the } \\
\text { specialty "Secondary Education } \\
\text { (Physical Education)" }\end{array}$ \\
\hline $\begin{array}{l}\text { Motivational } \\
\text { component }\end{array}$ & $36-54$ & $40-54$ \\
\hline $\begin{array}{l}\text { Cognitive } \\
\text { component }\end{array}$ & $24-36$ & 23 and less \\
\hline $\begin{array}{l}\text { Volitional } \\
\text { component }\end{array}$ & 35 and less & $36-54$ \\
\hline $\begin{array}{l}\text { Gnostic } \\
\text { component }\end{array}$ & $55-100$ & $68-108$ \\
\hline $\begin{array}{l}\text { Organizational } \\
\text { component }\end{array}$ & $27-40$ & $27-40$ \\
\hline $\begin{array}{l}\text { Self-government } \\
\text { Ability }\end{array}$ & 19 and less & 19 and less \\
\hline $\begin{array}{l}\text { Communicative } \\
\text { component }\end{array}$ & $20-30$ & $20-30$ \\
\hline
\end{tabular}

According to the research on the questions regarding their assessment of the presence and formation of the motivational-value component of their personal professional activity, both future teachers of physical culture and future managers of sports activity, the indicators of the first-year students have found an average level, not significantly increased in the future teachers of physical culture.

The analysis of the cognitive component revealed the average level of future managers of the sports industry, with the average low level of students in the field of physical education. Regarding the moral and will component, the indicators of the intermediate level were revealed in the future teachers of physical culture, with the predominantly low level of students of the specialty "Management in sports activities".

The Gnostic component showed an average, closer to a low level of first-year students in the specialty "Management in sports activities" and an average level of students in the specialty "Secondary education (Physical education)".

The analysis of the organizational component survey revealed an equal indicator of a stable average level of assessment of personal time planning and activity skills for the future profession. Self-government ability of first-year students of the Kharkiv State Academy of Physical Culture was expected to be low. Instead, the communicative component showed a stable average in all the students surveyed.

Also, a comparative characteristic of the average values of partial readiness for the professional and pedagogical self-development of students of the first year of the Kharkiv 
State Academy of Physical Culture in the specialties "Management in sports activity" and "Secondary education (Physical education)" was conducted. The results of the study are presented in Figure 1.

The average values in organizational and communicative components, as well as the ability to self-government, are the same in the first-year students in the specialties "Management in sports activities" and "Secondary education (Physical education)". Gnostic and volitional components are significantly higher in students of the specialty "Secondary Education (Physical Education)", and the average of the cognitive component is higher in students of the specialty "Management in sports activities". It should also be noted that the indicators of the motivational component in both specialties are almost the same.

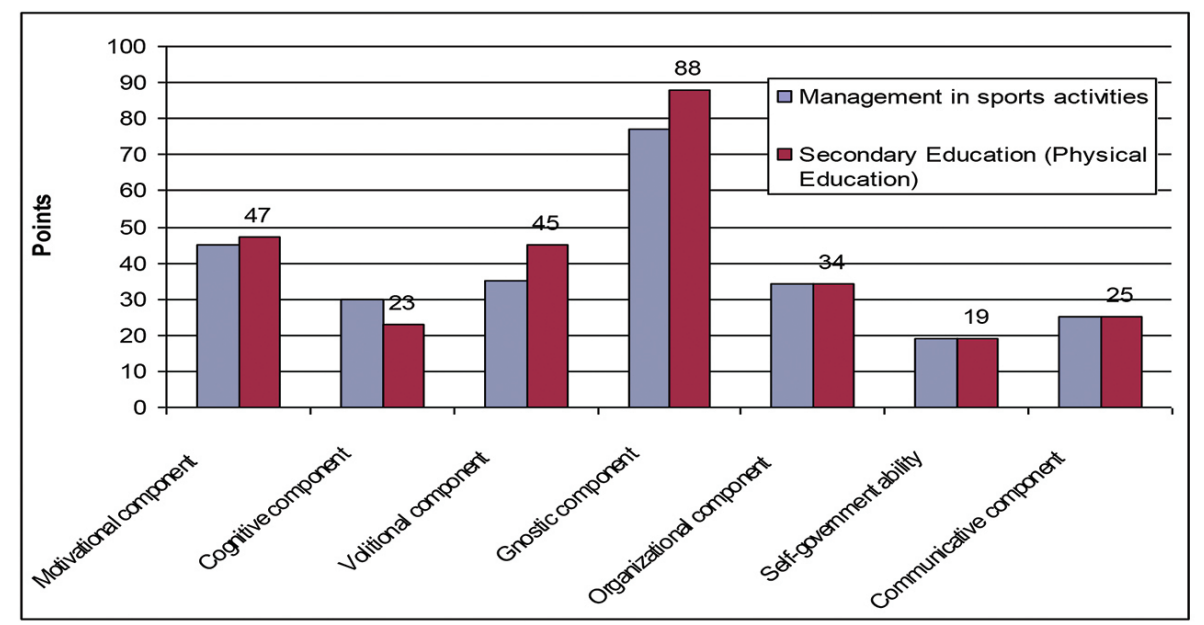

Figure 1. Comparative Characteristic of Partial Readiness for the Professional and Pedagogical Self-development of the First-year Students

Based on the analysis of the survey data, we conclude that the components we selected to start analyzing the professional competence of future professionals in the sports industry showed mostly expected levels as for the first-year students. We can also conclude that there is an insufficient level of self-government and awareness among the students of the first year of the studied areas. This indicates a lack of theoretical knowledge about professional culture and management and its role in professional activity.

The same questionnaire was offered to fourth year students in the specialties Management in Sporting Activities and Secondary Education (Physical Education). The obtained data were analyzed and reported in Table 2. 
Table 2

Partial Readiness for Professional and Pedagogical Self-Development

\begin{tabular}{lcc}
\hline \multicolumn{1}{c}{ Components } & $\begin{array}{c}\text { Fourth-year students } \\
\text { in the specialty "Manage- } \\
\text { ment in sports activities" }\end{array}$ & $\begin{array}{c}\text { Fourth-year students in } \\
\text { the specialty "Secondary } \\
\text { Education (Physical } \\
\text { Education)" }\end{array}$ \\
\hline Motivational component & 55 and more & 55 and more \\
Cognitive component & 36 and more & $24-40$ \\
Volitional component & 40 and more & 54 and more \\
Gnostic component & 100 and more & 108 and more \\
Organizational component & 40 and more & 40 and more \\
Self-government Ability & 30 and more & 30 and more \\
Communicative component & 31 and more & 31 and more \\
\hline
\end{tabular}

Analysis of the data on the motivational component of all interviewed students showed a high level of awareness of personal importance and the desire for professional development. The level of cognitive component formation exceeded among the surveyed students in the specialization "Management in sports activities" and reached a high level, but future teachers of physical education found a stable average, close to a high level. Not significantly different indicators of the volitional component prevailing among students in the specialization "Secondary Education (Physical Education)".

The analysis of indicators of gnostic and organizational components in general coincide and reveal a high level of formation of skills and abilities of systematization, synthesis, and actualization of the acquired knowledge in professional activity. Indicators of the communicative component and ability to self-identify revealed a consistently high level of formation of skills and skills of all interviewed future specialists in physical education.

A comparative characteristic of the average values of partial readiness for the professional and pedagogical self-development of the students of the fourth year of the Kharkiv State Academy of Physical Culture in the specialties "Management in sports activities" and "Secondary education (Physical education)" is conducted. The results of the study are presented in Figure 2. 


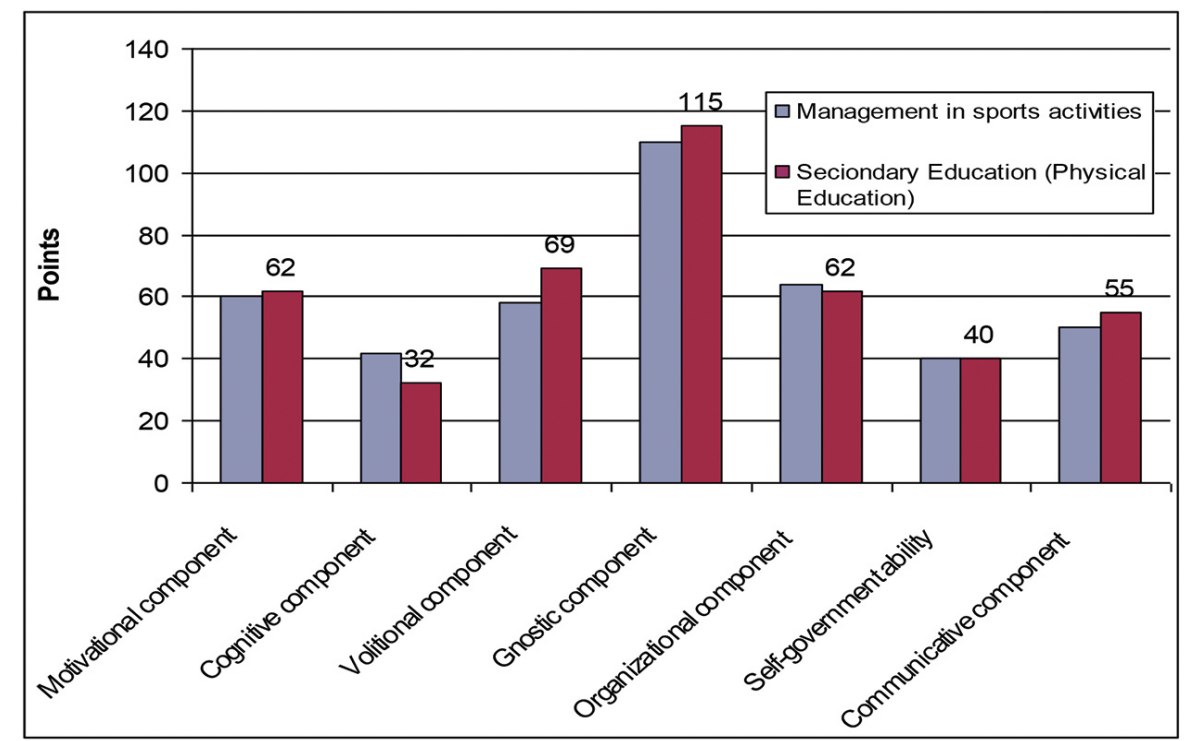

Figure 2. Comparative Characteristic of Partial Readiness for the Professional and Pedagogical Self-development of the Fourth-Year Students

The average indicators of partial readiness for professional and pedagogical selfdevelopment of students of the 4th year of Kharkiv State Academy of Physical Culture in the specialties "Management in sports activity" and "Secondary education (Physical culture)" are considered and it is concluded that the values of almost all components are at the same level, except cognitive and volitional components whose performance is significantly different.

\section{Discussion}

According to the analysis of indicators, there is a tendency of predominance in cognitive, volitional, and gnostic components. Other indicators found satisfactory but not sufficiently high levels of selected components.

Comparative analysis of the surveyed students of the same specializations of the first and fourth years revealed not only the tendency of preference of indicators of some components, but also, due to the experience of studying, the constant growth of indicators of all selected components as a whole.

The modern pace of development of our country's society sets a qualitatively new task in the field of education and professional development - the main driving force of social and cultural progress. The global goal of education at the present stage of development of our country is to prepare a specialist capable of realizing himself in a complex, multifaceted, 
and contradictory world, to actively and creatively apply the acquired knowledge and thereby contribute to the development of the culture of the whole society.

The modern requirements for the professional training of specialists provide for the comprehensive development of the individual, the formation of his mentality, self-awareness, and improvement. As a result, the requirements for the preparation of future graduates of universities have increased significantly, which means that the aim of the scientific-educational process of higher education institutions is to create such pedagogical conditions for the preparation of students, under which competent, flexible, competitive specialists graduate.

\section{Conclusion}

According to the research data, it can be stated that the formation of vocational competence of future specialists in physical education and sports is an integrated part of formatting high-level specialists in the field of sports and physical culture. The components presented by us provide an opportunity to study the level of vocational competence of future specialists of physical culture and sports and to further diagnose the formation of professional competence of future specialists of the sports industry. Analysis of indicators of chosen components shows that there is a necessity for deep investigation of vocational competence of future specialists in physical education and sports. The present results can help university teachers not only to diagnose, but also to create professional competence of future specialists in sports.

Generally, the analysis of obtained data once again proves the need for further larger-scale research in the field of vocational competence of future specialists in physical education and sports.

\section{References}

Aghae, N., Saffari, M., \& Hoseini F. S. (2018). Recognition of professional competence of physical education teachers with grounded theory approach. JRSM, 7(14), 71-83. http://jrsm.khu.ac.ir/ article-1-2660-en.html.

Akapiev, V. L., \& Savotchenko, S. E. (2016). On the issue of systematizing the concept of professional competence of a teacher and its application component. ProfessionalnayaPedagogica, 2, 21-30. https://article/n/professionalnaya-pedagogicheskaya-kompetentnostuchitelya-fenomenologiya-ponyatiya

Awad, K., \& Eid, I. (2013). Teaching competencies of physical education teachers in primary education (comparative study between accredited and non-accredited schools). Turkish Journal of Sport and Exercise, 15 (2), 16-20. https://dergipark.org.tr/tr/download/article-file/200712 
Bermudes, D., \& Loza, T. (2017). Professional and pedagogical activity of teachers of physical culture. Young Scientist, 3(1), 40-44 http://nbuv.gov.ua/UJRN/molv_2017_3.1_14

Chen, A., \& Ennis, C. D. (2004). Goals, interests, and learning in physical education. The Journal of Educational Research, 97(6), 329-338. https://libres.uncg.edu/ir/uncg/f/C_Ennis_ Goals_2004a.pdf

Chun-Chieh Kao, \&Yu-Jy Luo. (2019). The influence of low-performing students' motivation on selecting courses from the perspective of the sport education model. Physical Education of Students, 23(6) 269-278. https://doi.org/10.15561/20755279.2019.0601

Darla, M. \& Castelli, Beighle, A. (2007). The physical education teacher as school activity director. Journal of Physical Education, Recreation \& Dance, 78(5), 25-28, doi:10.1080/07303084.200 7.10598020

Derkach, A., \& Zazykin, V. (2003). Acmeology. Moscow: RAGS. https:/www.twirpx.com/ file/741772/

Dmitrenko, N. (2016). The implementation of problem-based learning in Ukrainian higher educational institutions. Novitnya Istoria, 5, 102-105. doi:https://doi.org/10.20535/24108286.61834 .

Dubrevskiy, Y. M. (2014). Qualitative and structural analysis of the managerial competency of future physical education and sport specialists. Pedagogics, Psychology, Medical-Biological Problems of Physical Training and Sports, 18(6), 11-15. http://dx.doi.org/doi:10.6084/ m9.figshare.1003973

Ennis C. D. (2013). Reimagining professional competence in physical education. Motriz: Revista de Educacao Fisica, UNESP, 19(4), 662-672. https://doi.org/10.1590/s1980-65742013000400001

Erturan, R., McBride, M., \& Agbuga, L. (2020). Self-regulation and self-efficacy as mediators of achievement goals and leisure time physical activity: a proposed model. Pedagogics, Psychology Medical-Biological Problems of Physical Training and Sports, 24(1), 12-20. doi:https:/doi. org/10.15561/26649837.2020.0102

Fedorenko, O. (2018). The content of professional competence of a lawyer. Pedagogical Innovations: Ideas, Realities, Prospects, 1, 87-93. http://nbuv.gov.ua/UJRN/ped_in_2018_1_13

Fetiskin, N. P., Kozlov, V. V., \& Manuylov, G. M. (2002). Socio-psychological diagnostics of personality development and small groups, 421-424. Moscow: Publishing House of the Institute of Psychotherapy.

Harmash, T. (2017). Model enabling the formation and development of the management competence of the future specialists in logistics. Scientific Bulletin of South Ukrainian National Pedagogical University Named After K.D.Ushynsky, 6(119), 27-32. http://er.nau.edu.ua:8080/ handle/NAU/36094

Hnatenko, K. V. (2019). Professional culture of the future trainer-teacher. Innovative Pedagogy, 13 (1), 36-39. https://doi.org/10.32843/2663-6085-2019-13-1-7

Kartseva, T. (2013). Evaluation of the effectiveness of the head: social orientation. Civil Service, 2, 107-109. https://pa-journal.igsu.ru/articles/r47/1910/ 
Khan, W., Arif, T., \& Khan, S. (2019). Role of sports activities in developing the important life skill of decision making; a psychological perspective. Physical Education of Students 23(4), 179-185. https://doi.org/10.15561/20755279.2019.0403

Kovač, M., Sloan, S., \& Starc, G. (2008). Competencies in physical education teaching: Slovenian teachers' views and future perspectives. European Physical Education Review, 14(3), 299-323. https://doi.org/10.1177/1356336X08095668

Kovalenko, R. (2015). Trade relations of Ukraine and European Union: European integration aspect. Journal L'Association 1910 «Sepike», Social Education Project of Improving Knowledge in Economics, 10, 91-95. https://sepik1.wixsite.com/sepikecloud/kopie-von-journal-04-2015-ed-11

Kovalenko, Yu. M. (2019). Theoretical principles of forming the administrative competence of future managers of sports activities. Innovative Pedagogy, 13(1), 75-78. https://doi. org/10.32843/2663-6085- 2019-13-1-16.

Kryshtanovych, S. V. (2018). Formation of administrative competence for future factors of physical culture and sports. Naukowyi Chasopys National Pedagogical Dragomanov University, 5(64), 120-123. http://www.chasopys.ps.npu.kiev.ua/archive/64-2018/64-2018.pdf

Kudryavtsev, M. D., Kramida, I. E. (2018). Qigong training as a successful factor of fighter's personal qualities development in students. Physical Education of Students, 22(4), 190-195. https://doi.org/10.15561/20755279.2018.0404.

Kuzmina, N. V. (2014). Creative vector of fundamental education. Innovative Approaches to the Education of Student Youth in Higher Education, 20-78. http://eprints.zu.edu.ua/18226/1/ Кузьмина\% $20 \mathrm{H}$

Liashenko, V. N., Tumanova, V. N., \& Hatsko, E. V. (2016). Study of personality's temperament and self-assessment of higher educational establishments' students. Physical Education of Students, 19-23. https://doi.org/10.15561/20755279.2016.0203.

Melnychenko, A., Akimova, O. (2013). Developing competences of public managment and administration specialists: Implementation of foreign experience in Ukraine. Advanced Education, 6(13), 89-96. doi:http://dx.doi.org/10.20535/2410-8286.184575

Michuda, YU. P. (2007). Socio-economic aspects of sports development for all. Proceedings of XI International Scientific Congress "Modern Olympic Sports and Sports for All". Moscow. http://www.disslib.org/funktsionuvannja-ta-rozvytok-sfery-fizychnoyi-kultury-i-sportu-vumovakh-rynku.html

Osadcha, T. (2006). Formation of professional skills of future teachers of physical education (on the example of educational programs of US universities): scientific method. Manual Lugansk: Alma Mater, 2, 130-143. http://www.irbis-nbuv.gov.ua/cgi-bin/irbis_nbuv/cgiirbis_64.exe?Z2

Paula, M., Fazendeiro, B., Amândio, B., \& Zélia M. (2011). The place of knowledge in the representation of professional competence held by PE teachers. eJournal de la Recherche sur l'intervention en Education Physique et Sport, 24, 96-117. https://doi.org/10.4000/ejrieps.4027 Rychkova, M. (2016). Features of physical education in US universities. Pedagogical Sciences: Theory, History, Innovative Technologies, 4 (58), 55-60.http://nbuv.gov.ua/UJRN/pednauk_2016_4_10 
Rzhevska-Shtefan, Z. (2018). Future psychologists experiencing the crisis of professional selfdetermination: Features of motivational sphere. Novitnya Istoria, 10, 21-26. https://doi. org/10.20535/2410-8286.115903

Schnitzius, M., Kirch, A., Mess, F., \& Spengler, S. (2019). Inside Out: A scoping review on the physical education teacher's personality. Frontiers in Psychology, 10, 54-68. https://doi. org/10.3389/fpsyg.2019.02510

Shumigora, L. (2019). Competence-oriented model of a higher school teacher. Continuing Professional Education: Theory and Practice, 3, 13-21. http://dx.doi.org/10.28925/16098595.2019.3.1321

Srisawat, P., Buppaworng, N., \& Wongwirat, Yu. (2015). Model for development of professional competencies of physical education teacher in 21 st century in educational innovation and information Technology. The Twelfth International Conference on eLearning for KnowledgeBased Society, 57, 1-6.http://www.ijcim.th.org/SpecialEditions/v23nSP2/02_57A_Model.pdf

Svertnev, O. A. (2018). Characteristics of the main competences of the manager of physical culture and sports in the current conditions of higher education reforming. Image of the Modern Pedagogue, 7(176), 19-22. http://dx.doi.org/10.33272/2522-9729-2017-7 (176)-19-22

Synekop, O. (2018). Cognitive aspect of learning style in differentiated ESP instruction for the future IT specialists. Novitnya Istoria, 10, 89-93. doi:https://doi.org/10.20535/2410-8286.151271

Uğraş, L., \& Özen, J. (2020). Investigation of relationship between attitude to physical education course and school belonging. Pedagogics, Psychology, Medical-Biological Problems of Physical Training and Sports, 24 (1), 48-53. https://doi.org/10.15561/26649837.2020.0108

Zelenskyi, B., \& Zelenskyi, R. (2018). Motivation: the attitude of students of higher educational institutions of I-II levels of accreditation to classes on the subject of "Physical Education". Theory and Methods of the Physical Education, 18(3), 56-62. https://doi.org/10.17309/ tmfv.2018.3.02

Zhu X, Ennis C. D., \& Chen A. (2011). Implementation challenges for a constructivist physical education curriculum. Physical Education and Sport Pedagogy, 16, 83-99. http://dx.doi. org/10.1080/17408981003712802

Zhyhir, V. (2015). The model of professionally pedagogical competencies formation of future education Managers. Pedahohika Formuvannya Tvorchoyi Osobystosti u Vyshchiy $i$ Zahal'Noosvitniy Shkolakh, 43(96), 122-129. http://nbuv.gov.ua/UJRN/Pfto_2015_43_19. 


\title{
Būsimụjų kūno kultūros ir sporto specialistų profesinès kompetencijos formavimas
}

\author{
Julia Kovalenko $^{1}$, Kateryna Gnatenko ${ }^{2}$, Olena Fedorenko ${ }^{3}$, Lubov Karpets ${ }^{4}$, Roman Kovalenko ${ }^{5}$ \\ 1 Charkovo valstybinẻ kūno kultūros akademija, Klochkivska g. 99, UA-61058 Charkovas, Ukraina, \\ julawa09@gmail.com \\ 2 Charkovo valstybinè kūno kultūros akademija, Klochkivska g. 99, UA-61058 Charkovas, Ukraina, \\ malekk26@gmail.com \\ 3 Charkovo nacionalinis vidaus reikalų universitetas, Landau aleja 27, UA-61080 Charkovas, Ukraina, \\ fei090771@gmail.com \\ 4 Charkovo valstybinè kūno kultūros akademija, Klochkivska g. 99, UA-61058 Charkovas, Ukraina, \\ lubo.karpets@gmail.com \\ 5 V. N. Karazino Charkovo nacionalinis universitetas, Svobody skveras 4, UA-61022 Charkovas, Ukraina, \\ roman.kovalenko@karazin.ua
}

\section{Santrauka}

Straipsnyje nagrinėjamas būsimųjų kūno kultūros ir sporto specialistų profesinès kompetencijos formavimas. Buvo apklausta 40 Ukrainos Charkovo valstybinès kūno kultūros akademijos pirmojo ir ketvirtojo kurso studentų. Pasirinkti atitinkami komponentai būsimųjų sporto profesionalų profesinei kompetencijai analizuoti. Tyrimas rodo, kad yra nepakankama pirmųjų metų studentų savivalda ir sąmoningumas tirtose srityse. Vadinasi, trūksta teorinių žinių apie profesinę kultūrą ir vadybą bei jos vaidmenį profesinèje veikloje. Apsvarstyti Charkovo valstybinès kūno kultūros akademijos 4 kurso studentų specialybių „Sportinès veiklos vadyba“ ir „Vidurinis ugdymas (kūno kultūra)“ dalinio pasirengimo profesinei ir pedagoginei saviugdai rodikliai. Daroma išvada, kad beveik visų komponentų vertės yra vienodos, išskyrus pažintinius ir valios komponentus, kurių veikimas labai skiriasi. Dẻl to labai išaugo reikalavimai būsimųjų universitetų absolventų pasirengimui, o tai reiškia, kad aukštųjų mokyklų mokslinio-edukacinio proceso tikslas yra sukurti tinkamas pedagogines sąlygas kompetentingiems, lankstiems ir konkurencingiems specialistams ruošti.

Esminiai žodžiai: kompetencija, profesine kompetencija, sporto specialistai, kūno kultūra, vadyba, profesinè kultūra. 